\title{
Academic Stress and Spiritual Well-Being in Riau
}

\author{
Wiwied Widiyanti ${ }^{1}$, Juntika Nurihsan ${ }^{2}$, Syamsu Yusuf LN 3, Nandang \\ Budiman4, Hendriadi5
}

DOI : $10.35445 /$ alishlah.v13i3.361

\section{Article Info Abstract}

Keywords:

Spiritual well-being;

Academic stress

Kata kunci:

Kesejahteraanspiritual;

Stresakademik
The purpose of this study was to develop a profile of spiritual well-being and academic stress among students in high schools and universities and determine whether there is a relationship between academic stress and spiritual well-being among students in the Indragiri Hulu district of the province of Riau, Indonesia. The quantitative technique is used in this investigation. It was decided to employ a survey design for this investigation. 105 students were chosen to participate in the survey, with an 81 per cent response rate $(n=85)$. Academic stress was reported by 82 per cent of those who answered the survey questions (70 people). Additionally, according to the findings of this study, women suffer more stress than males, and students in college experience more stress than students in high school. Academic stress, on the other hand, is not significantly associated with gender or educational level. In contrast, the spiritual well-being of students is associated with just a slight link with the academic stress experienced by students.

\begin{abstract}
Abstrak
Tujuan penelitian ini adalah untuk mencari profil kesejahteraan spiritual dan stres akademik pelajar di Sekolah Menengah Atas (SMA) dan Perguruan Tinggi, serta mencari korelasi antara stres akademik dan kesejahteraan spiritual pelajar yang ada di kabupaten Indragiri Hulu, Provinsi Riau. Penelitian ini menggunakan pendekatan kuantitatif. Disain yang digunakan pada penelitian ini adalah penelitian survey. Ada 105 pelajar yang terpilih menjadi responden, dengan respon sebesar $81 \%(n=85)$. Jumlah responden yang mengalami stres akademik sebesar $82 \%$ ( 70 orang). Penelitian ini juga menemukan bahwa wanita lebih banyak mengalami stres dibandingkan pria, pelajar yang berada di perguruan tinggi lebih banyak mengalami stres dibandingkan dengan pelajar yang berada di sekolah menengah. Namun, gender, tingkat pendidikan tidak signifikan memiliki korelasi dengan stres akademik, sedangkan kesejahteraan spiritual yang dimiliki pelajar memiliki korelasi yang lemah dengan stres akademik yang dialami pelajar.
\end{abstract}

\footnotetext{
${ }^{1}$ Un iv ersitas Pendidikan In donesia, Bandung, In donesia

Em ail: widyawidi84@gmail.com

2 Universitas Pendidikan In donesia, Bandung, In donesia

Em ail: juntikanurihsan@upi.edu

3 Univ ersitas Pendidikan In donesia, Bandung, In donesia

Em ail: syamsu@upi.edu

4 Un iv ersitas Pendidikan In donesia, Ba ndung, In donesia

Em ail: nandang.budiman@upi.edu

5 Kem entrian Agama Kabupaten In dragiri Hulu, Rengat, In donesia

Em ail: colhendri@yahoo.co.id
} 


\section{INTRODUCTION}

After the second World War, the Covid-19 pandemic was the disaster that caught the world's attention the most (I. \& P., 2020). The origin of Covid-19 itself is still a mystery, but epidemiologically it is thought to have occurred in a fish market in the city of Wuhan, Hubei Province, China(Susilo et al., 2020; Wang, Pan, Wan, Tan, Xu, H o, et al., 2020). This virus was only discovered in December 2019, on January 24, 2020, it spread to 13 countries and then more than 100 countries became infected (Fardin, 2020; Shereen, Khan, Kazmi, Bashir, \& Siddique, 2020; Susilo et al., 2020; Wang, Pan, Wan, Tan, Xu, McIntyre, et al., 2020) According to the World Health Organization (WHO), this pandemic takes not only human lives but also creates economic and social problems for the community (Kowalczyk et al., 2020). In addition, the Covid-19 pandemic has put humans in psychological problems such as fear, anxiety, and suffering (Kowalczyk et al., 2020). Stress, depression, and anxiety in the Covid-19 pandemic have resulted in physical illnesses such as chills, muscle aches, coughs, dizziness, coryza (acute inflammation of the mucous membranes of the nasal cavity) and sore throat (Wang, Pan, Wan, Tan, Xu, Ho, et al., 2020).

Before the Covid-19 pandemic, the results of research conducted by Taufik and Ifdil (2013) in public high schools in Padang were that $13.2 \%$ experienced high levels of academic stress, $71.8 \%$ experienced moderate levels of academic stress and $15 \%$ experienced low levels of stress. The COVID-19 pandemic also threatens the psychological condition of students. As a result of the change in the learning system, which was previously face-to-face, it has now been changed to a Distance Learning System (PJJ). Students who are in higher education also experience stress due to changes in the learning system (Livana, Mubin Mohammad Fatkhul \& Basthomi, 2020). Of the 190 students studied, 79 experienced mild anxiety, 23 experienced mild stress, and 7 experienced mild depression (Hasanah, Ludiana, Immawati, \& PH, 2020). In other countries such as the United States, of the 195 students studied, $71 \%$ or 138 people experienced increased stress and anxiety due to the Covid-19 pandemic (Son, Hegde, Smith, Wang, \& Sasangohar, 2020). In Ethiopia, as many as 322 people studied, 21.2\% experienced depression, $27.7 \%$ experienced anxiety and $32.5 \%$ experienced stress (Aylie, Mekonen, \& Mekuria, 2020).

Harrington (2012) defines stress as a form of cognitive, affective, physiological, and behavioural reactions in humans due to situations that threaten them. Stress is a psychological condition with a long range that affects a person's psychological arousal, which leads to a negative mood, affects cognitive capacity, physical health and also affects a person's immune system (Matsumoto, 2009:524; S. Menaga, 2014). In other words, stress causes a change that occurs in the body and mind, contributes to psychological (mental health) and physiological (physical) disorders, which have an impact on the person's low quality of life (VandenBos, 2015:1036).

Academic stress is a combination of academic demands and individual adaptability (Wilks, 2008). Academic stress is a reaction to pressure from school or education (S. Menaga, 2014). Humans and the environment is a complex combination of stress (Lazarus \& Cohen, 1977). Parents assume that learning will not bring their children to stressful conditions (Reddy, Menon, \& Thattil, 2018). However, it is precisely stress that is vulnerable to adolescence because it is burdened by parents' wishes who want to learn values according to the expectations they have set. Stress brought on both the hope of receiving excellent scores and the dread of receiving poor grades (Pascoe, Hetrick, \& Parker, 2019). It is also said by Fröjd et al. (2008) that depression experienced by students, often occurs due to low points on academic achievement or also the number of academic achievement points that decrease from previous academic achievements. Academic stress can be initiated by a feeling of failure to meet the expectations that are imposed so that it leads to conditions of stress and depression (Sarita \& Sonia, 2015). This academic pressure will lead to tension in the face of career and future (Sarita \& Sonia, 2015). This situation makes academic performance worse (Owens, Stevenson, Hadwin, \& Norgate, 2012). 
Adolescents who experience depression or anxiety in their academic perfor mance caused by family factors or individual factors for an extended period can experience poor mental health in the future. At the ages of 13 and 15, when they were depressed, they were more likely to experience depression again between the ages of 36 and 53. In addition, students who have attempted suicide before have also attempted suicide or at least had suicidal ideation (Fergusson, Boden, \& Horwood, 2007). Predictors of academic stress triggers can be academic pressure, satisfaction, locus of control and gender (Karaman, Lerma, Vela, \& Watson, 2019). In addition to academic stress, a study conducted by Abdulghani, AlKanhal, Mahmoud, Ponnamperuma, \& Alfaris (2011) found that physical problems correlate with stress levels.

Stress in high school and college students is also described by Pascoe et al. (2019) has negative impacts such as learning ability, academic performance, mental and physical health, sleep quality and quantity, use of illegal drugs, education and achievement in students. For this reason, according to Pascoe et al. (2019), it is necessary to have an ability and skill in stress management for students. According to Almigbal (2015) research results, high stress among academics indicates the need to establish a mental health and counselling service.

Spiritual welfare is an important variable in human life on this earth. In addition to having an important role and benefits for human life (Brown, 2012; Ekşi \& Kardaş, 2017), spiritual well-being can provide various other benefits for academic life (Muñoz-garcía \& Aviles-herrera, 2014). In Indonesia, spirituality and religion are integrated into the National Education System Law to obtain superior future generations. At the beginning of Indonesia's independence, the 1945 Constitution of the Republic of Indonesia was issued, which mandates the Indonesian Government to seek and organize a national education system that increases faith and piety to God Almighty and noble character in the context of educating the nation's life which is regulated in law.This became the basis for the issuance of the National Education System Law or abbreviated as the National Education System Law no. 20 of 2003 in the article (4), which reads "national education aims to develop the potential of students to become human beings who believe and fear ...".

Spirituality and religion are characteristics of humans, where there is a belief and a practice that is carried out based on that belief. This belief is persuasive, stable, and pervasive in the human psyche, where humans believe that there is a transcendent or non-physical dimension (Peterson \& Seligman, 2004:600). According to Ellison (1983), spiritual well-being refers to a person's tendency to have a meaningful life and life purpose without anything to do with religion, which is also called existential welfare. Not only that, according to Ellison (1983), spiritual well-being also refers to the relationship between humans and their God, which is called religious welfare. (Fisher, 2011) mentions that humans intentionally create spiritual well-being to develop themselves, which is spiritual well-being.

Based on a study conducted, religious denominations and satisfaction with life values can provide academic success. Spiritual-based coping strategies provide benefits for academic achievement and success for educational institutions (Cox, 2011). Spiritual well-being is also useful for overcoming the problem of academic dishonesty (Muñoz-garcía \& Aviles-herrera, 2014). It is also said that religious beliefs and rituals can be a coping strategy to deal with problems of anxiety, stress and even depression (Musa, Pevalin, \& Al Khalaileh, 2018). Research conducted by Cox (2011) previously correlated spirituality, stress and academic performance where he found no correlation between spirituality and anxiety and no correlation between stress and academic performance. Meanwhile, Alsalhi, Almigbal, Alsalhi, \& Batais (2018) investigated the relationship between stress and academic achievement, where they found that high stress resulted in poor academic performance.

However, due to the large number of studies that reveal contradictory relationships between spirituality and academic stress, the scope of research is limited. This research is needed to see the relationship between spiritual well-being and academic stress experienced by students in Riau 
during this pandemic. It is hoped that this research will become a reference in making decisions to implement appropriate and efficient interventions in dealing with academic stress problems.

\section{METHODS}

This study uses a cross-sectional research method by looking at the correlation between spiritual well-being and academic stress on students in the Indragiri Hulu area, Riau. The target respondents in this study were aged 18 to 22 years who were in middle school to college in Indragiri Hulu, Riau. Sample size in correlation research is at least 30 people (Gay, L.R. \& Diehl, 1992). However, in this study, we took a sample of 85 people. The larger the number of samples taken, the better and more representative (Gay, L.R. \& Diehl, 1992).

The instrument used to measure spiritual well-being is the Spiritual Well-Being Scale (SWBS) instrument developed by Ellison (1983), consisting of 20 question items adapted into Indonesian. By giving a score from 1 to 6 , with the answer choices "strongly agree", "moderately agree", "agree", "disagree", moderately disagree", and "strongly disagree". The respondent's highest answer score is 120 points, and the lowest score is 20 points. The instrument was tested for validity (see table 1. Validity test) and reliability (see table 2. Recapitulation of Spiritual Well-Being Instrument Reliability Test).

Table 1. Recapitulation of Instrument Validity Test Spiritual Well-being

\begin{tabular}{|c|c|c|}
\hline Statement Items & $\begin{array}{l}\text { Correlation } \\
\text { coefficient ( } \\
\text { r) }\end{array}$ & Information \\
\hline 1. I find no satisfaction in praying with God & $0.416^{* *}$ & Valid \\
\hline $\begin{array}{l}\text { 2. I don't know who I am, where I come from and where I'm } \\
\text { going }\end{array}$ & $0.440^{* *}$ & Valid \\
\hline 3. I believe that God loves me and cares for me & $0.471^{* *}$ & Valid \\
\hline 4. I feel life is a positive experience & $0.405^{* *}$ & Valid \\
\hline 5. I believe that God is not interested in my life & $0.493^{* *}$ & Valid \\
\hline 6. I feel uncomfortable with my future & $0.578^{* *}$ & Valid \\
\hline 7. I have a meaningful personal relationship with God & $0.433^{* *}$ & Valid \\
\hline 8. I feel very satisfied with the life I have & $0.459^{* *}$ & Valid \\
\hline 9. I don't feellike I get much strength and support from God & $0.633^{* *}$ & Valid \\
\hline 10. I feel I have a purpose in life that is prosperous & $0.365^{* *}$ & Valid \\
\hline $\begin{array}{l}\text { 11. I believe that God cares about the problems I'm } \\
\text { experiencing }\end{array}$ & $0.491^{* *}$ & Valid \\
\hline 12. I don't really enjoylife & $0.515^{* *}$ & Valid \\
\hline 13. I personally do not have a satisfying relationship with God & $0.539^{* *}$ & Valid \\
\hline 14. I feel happy with my future & $0.450^{* *}$ & Valid \\
\hline 15. My relationship with God helps me not to feel lonely & $0.353^{* *}$ & Valid \\
\hline 16. I feel that my life is full of conflict and unhappiness & $0.428^{* *}$ & Valid \\
\hline 17. I feel satisfied when I am in a close relationship with God & $0.504^{* *}$ & Valid \\
\hline 18. Life doesn't have much meaning & $0.473^{* *}$ & Valid \\
\hline $\begin{array}{l}\text { 19. My relationship with God contributes to a feeling of well- } \\
\text { being }\end{array}$ & $0.442^{* *}$ & Valid \\
\hline 20. I believe there is a real purpose in my life & $0.379^{* *}$ & Valid \\
\hline
\end{tabular}

*. Correlation is significant at the 0.05 level (2-tailed)

**. Correlation is significant at the 0.01 level (2-tailed)

Table 2. Recapitulation of Instrument Reliability Test

\begin{tabular}{cc}
\multicolumn{3}{c}{ Spiritual Well-being } \\
\hline \multicolumn{2}{c}{ Reliability Statistics } \\
\hline Cronbach's & $\mathrm{N}$ of \\
Alpha & Items \\
.723 & 21 \\
\hline
\end{tabular}


In testing the instrument's validity, if $t_{\text {count }}$ is greater than $t_{\text {table }}$ then the instrument is said to be valid (Sundayana, 2010:61). Based on Table 1, recapitulation of the welfare Instrument validity test above, all of the spiritual welfare items developed by Ellison after adaptation to Indonesian showed valid results. In testing the reliability of the instrument, Guilford criteria for reliability. The coefficient of 0.723 belongs to high reliability (Sundayana, 2010:71). The Academic Stress Scale (ASS) instrument developed by (Kohn \& Frazer, 1986) consists of 33 statement items adapted into Indonesian to measure academic stress. By giving a score from 1 to 5, with the answer choices "not stressed", "often stressed", "sometimes stressed", "always stressed", and "very stressed". The highest answer score is 165 points, and the lowest answer score is 33 points.

Table 3. Recapitulation of Instrument Validity Test Academic Stress

\begin{tabular}{|c|c|c|}
\hline $\begin{array}{c}\text { Statement Items } \\
\text { Conditions that Cause Stress (Stressors) }\end{array}$ & $\begin{array}{l}\text { Correlation } \\
\text { coefficient ( } \\
\text { r) }\end{array}$ & Information \\
\hline 1. Finalscore & $0.401^{* *}$ & Valid \\
\hline 2. A lot of homework (PR) & $0.346^{* *}$ & Valid \\
\hline 3. Papers & 0.185 & Invalid \\
\hline 4. Exam & $0.228^{*}$ & Valid \\
\hline 5. Study for exams & 0.213 & Invalid \\
\hline 6. Paper presentation & $0.437^{* *}$ & Valid \\
\hline 7. Waiting for the promotion test & $0.413^{* *}$ & Valid \\
\hline 8. Lecturer/teacher speaks toofast & $0.470^{* *}$ & Valid \\
\hline 9. Quiz & $0.401^{* *}$ & Valid \\
\hline 10.Forgot to do homework & $0.533^{* *}$ & Valid \\
\hline 11. Unfinished task & $0.647^{* *}$ & Valid \\
\hline 12. The task is not clear / not understood & $0.584^{* *}$ & Valid \\
\hline 13. Not ready to respond to questions & $0.613^{* *}$ & Valid \\
\hline 14. The announcement will be a quiz & $0.465^{* *}$ & Valid \\
\hline 15. Studying the wrong subject matter & $0.456^{* *}$ & Valid \\
\hline 16. Giving the wrong answer & $0.377^{* *}$ & Valid \\
\hline 17. No class & 0.153 & Invalid \\
\hline 18. Buying a textbook & 0.203 & Invalid \\
\hline 19. Learna newskill & $0.453^{* *}$ & Valid \\
\hline 20. Unclear course objectives & $0.497^{* *}$ & Valid \\
\hline 21. Hot study room & $0.322^{* *}$ & Valid \\
\hline 22. Learn a language & $0.551^{* *}$ & Valid \\
\hline 23. Boring class & $0.430^{* *}$ & Valid \\
\hline 24. Entered the wrong class & $0.573^{* *}$ & Valid \\
\hline 25. Class is late & 0.062 & Invalid \\
\hline 26. The study room is too cold & $0.571^{* *}$ & Valid \\
\hline 27. Too late & $0.468 * *$ & Valid \\
\hline 28. Forgot to bring a pencil/pen & $0.277^{*}$ & Valid \\
\hline 29. Take notes on the subject matter & $0.485^{* *}$ & Valid \\
\hline 30. When studying, there is noise & $0.640^{* *}$ & Valid \\
\hline 31. Lessons that are not relevant to the major & $0.402^{* *}$ & Valid \\
\hline 32. The class is too crowded & $0.223^{*}$ & Valid \\
\hline 33. Class without open discussion & $0.422^{* *}$ & Valid \\
\hline 34. Ev aluating the work of classmates & 0.211 & Invalid \\
\hline 35. Poor lighting & 0.105 & Invalid \\
\hline
\end{tabular}

* Correlation is significant at the 0.05 level (2-tailed)

**. Correlation is significant at the 0.01 level (2-tailed) 


\section{Table 4. Recapitulation of Instrument Reliability Test Academic Stress \\ Reliability Statistics \\ Cronbach's N of \\ Alpha Items \\ .733 29}

Then after testing the validity of the academic stress instrument using SPSS 16.00 for windows, 28 items were found to be valid statements, while seven items were not valid statements. For instrument reliability testing, items that are not valid are not included in the reliability test (Sundayana, 2010: 70). It can be seen from Table 4. Recapitulation of Reliability Test of Academic Stress Instruments, the reliability coefficient of 0.733 is categorized as high reliability.

\section{FINDINGS AND DISCUSSION}

There were as many as 105 questionnaire packages distributed, with up to 20 incompletely filled, based on the total number of questionnaire packages distributed. There were a total of 85 packages of questions that could be processed in one day. As observed in Table 5, student characteristics, the total number of respondents was 85 students, with more than half of the respondents being female, i.e. $70 \%$ or as many as 59 individuals. In contrast, male responders accounted for $30 \%$ of the total or as many as 26 individuals.

Table 5. Characteristics of Students $(n=85)$

\begin{tabular}{lll}
\hline & Variabel & $\mathrm{n}^{\mathrm{a}}(\%)$ \\
\hline Gender & Man & $26(30 \%)$ \\
& Woman & $59(70 \%)$ \\
Levelof education & Secondary school & \\
& College & $49(58 \%)$ \\
& & $36(42 \%)$ \\
Academic Stress & Tall & $14(18 \%)$ \\
& Currently & $56(66 \%)$ \\
& Low & $15(16 \%)$ \\
Spiritual Well-being & & \\
& Tall & $30(35 \%)$ \\
& Currently & $49(58 \%)$ \\
& Low & $6(7 \%)$ \\
\hline
\end{tabular}

Respondents in high school accounted for as many as 49 people, or approximately 58 per cent, of the total. In comparison, respondents in college accounted for as many as 36 people or approximately 42 per cent. It was discovered that, out of 85 responses, 14 persons experienced considerable academic stress, accounting for approximately 18 per cent of the total; 56 individuals, accounting for 66 per cent of the total; and 15 individuals, accounting for 16 per cent of the total. There are 30 individuals, or 35 per cent, who have a high level of spiritual well-being, 49 individuals, or 58 per cent who have moderate spiritual well-being, and 6 individuals, or 7 per cent, who have low spiritual well-being, based on the level of spiritual well-being among students.

The relationship between academic stress and student variables can be seen in that the number of stressed students is dominated by female students by $88 \%$ while male students by $69 \%$. This is similar to research in Saudi Arabia and America that stress is more common among women compared to men (Alsalhi et al., 2018; Misra \& Castillo, 2004). In life, women tend to be more influenced by stressors when compared to men (Mayor, 2015). Women react more to anger, 
anxiety, frustration and depression. Where anxiety and frustration are associated with stress in humans (Calvarese, 2015), another reason could be that women have less freedom compared to men to do activities to avoid stress (Alsalhi et al., 2018; Kumar \& Bhukar, 2013). If the statistical calculation of the significance value is greater than the alpha value ( $\alpha$ ), Ho is rejected (Sundayana, 2010:179). The calculation results using SPSS 16.00 for windows yielded a significance value of $0.073>=0.01$. This indicates that there is no significant difference between the academic stress of the male and female groups.

Table 6. The relationship between academic stress and student variables

\begin{tabular}{lllll}
\hline \multicolumn{2}{c}{ Variable } & Stress & No Stress & $\begin{array}{l}\text { Significance } \\
\text { Value }\end{array}$ \\
& & & & 0.073 \\
Gender & Man & $18(69 \%)$ & $8(31 \%)$ & \\
& Woman & $52(88 \%)$ & $7(12 \%)$ & \\
& & & & 0.362 \\
Levelofeducation & Secondary school & $40(80 \%)$ & $10(20 \%)$ & \\
& & & & \\
& College & $30(86 \%)$ & $5(14 \%)$ & \multirow{2}{*}{0.004} \\
Spiritual well-being & Tall & $27(90 \%)$ & $3(10 \%)$ & \\
& Currently & $41(84 \%)$ & $8(16 \%)$ & \\
& Low & $3(50 \%)$ & $3(50 \%)$ & \\
\hline
\end{tabular}

When viewed from the level of education, students experience more stress than students in high school, namely $86 \%$ and $80 \%$, respectively. However, if it is seen from the significance value of the results of statistical calculations using SPSS 16.00 for windows of $0.362>=0.01$, it can be concluded that there is no difference between the two groups of colleges and students. Although sometimes academic and environmental problems can be a stressor for college students (Yikealo, Yemane, \& Karvinen, 2018). However, stress can also positively impact students to make them think about the importance of being in college (Robotham, 2008). Meanwhile, students with a high level of well-being experience more stress, which is around 90\% compared to students who have moderate and low spiritual well-being with moderate and non-stressed levels of stress. From statistical testing using SPSS 16.00 for windows, a statistically significant value of 0.002 was obtained with a Pearson Correlation of 0.325. According to Khamis (2008), the value of $\mathrm{r}=0.3$ is interpreted as having a weak correlation.

\section{CONCLUSION}

It becomes homework for teachers and counsellors to assist children experiencing high and medium levels of stress, which accounts for 82 per cent of the population. Since academic stress and spiritual well-being have such a poor relationship, teachers and counsellors in schools and colleges must rethink service programs in order to give suitable treatments in dealing with students' academic stress concerns. Further research is required on the spiritual well-being variable in order to develop a spiritual welfare instrument that is appropriate for the conditions of the people in Indonesia, given that the spiritual well-being instrument developed by Ellison has a ceiling effect for Indonesians who adhere to religious beliefs. Furthermore, the tool devised by Ellison to discuss spiritual well-being continues to rely on limiting perspectives, particularly religion and existentialism. 


\section{REFERENCES}

Abdulghani, H. M., AlKanhal, A. A., Mahmoud, E. S., Ponnamperuma, G. G., \& Alfaris, E. A. (2011). Stress and its effects on medical students: A cross-sectional study at a college of medicine in Saudi Arabia. Journal of Health, Population and Nutrition. https://doi.org/10.3329/jhpn.v29i5.8906

Almigbal, T. H. (2015). Relationship between the learning style preferences of medical students and academic achievement. Saudi Medical Journal. https://doi.org/10.15537/smj.2015.3.10320

Alsalhi, A. H., Almigbal, T. H., Alsalhi, H. H., \& Batais, M. A. (2018). The relationship between stress and academic achievement of medical students in king saud university: A crosssectional study. Kuwait Medical Journal.

Aylie, N. S., Mekonen, M. A., \& Mekuria, R. M. (2020). The psychological impacts of COVID-19 pandemic among university students in bench-sheko zone, South-West Ethiopia: A community-based cross-sectional study. Psychology Research and Behavior Management. https://doi.org/10.2147/PRBM.S275593

Brown, P. (2012). Spiritual development. Early Years Educator, 14(7), viii-ix. https://doi.org/10.12968/eyed.2012.14.7.viii

Calvarese, M. (2015). The effect of gender on stress factors: An exploratory study among university students. SocialSciences. https://doi.org/10.3390/socsci4041177

Cox, C. J. (2011). The Relationship Between Spirituality, Stress, and Academic Performance. Bowling Green State University.

Ekşi, H., \& Kardaş, S. (2017). Spiritual Well-Being: Scale Development and Validation. Spiritual Psychology and Counseling, 2(1), 73-88. https://doi.org/10.12738/spc.2017.1.0022

Ellison, C. W. (1983). Spiritual Well-Being: Conceptualization and Measurement. Journal of Psychology and Theology.https://doi.org/10.1177/009164718301100406

Fardin, M. A. (2020). COVID-19 Epidemic and Spirituality: A Review of the Benefits of Religion in Times of Crisis. Jundishapur Journal of Chronic Disease Care. https://doi.org/10.5812/jjcdc.104260

Fergusson, D. M., Boden, J. M., \& Horwood, L. J. (2007). Recurrence of major depression in adolescence and early adulthood, and later mental health, educational and economic outcomes. British Journal of Psychiatry. https://doi.org/10.1192/bjp.bp.107.036079

Fisher, J. (2011). The four domains model: Connecting spirituality, health and well-being. Religions. https://doi.org/10.3390/rel2010017

Fröjd, S. A., Nissinen, E. S., Pelkonen, M. U. I., Marttunen, M. J., Koivisto, A. M., \& Kaltiala-Heino, R. (2008). Depression and school performance in middle adolescent boys and girls. Journal of Adolescence. https://doi.org/10.1016/j.adolescence.2007.08.006

Gay, L.R. \& Diehl, P. L. (1992). Research Methods for Business and Management New York: MacMillan Publishing Company. New York: MacMillan Publishing Company.

Harrington, R. (2012). Stress, Health and Well-Being: Thriving In The 21 st Century. United States of America: Jon-David Hague.

Hasanah, U., Ludiana, Immawati, \& PH, L. (2020). Gambaran Psikologis Mahasiswa Dalam Proses Pembelajaran Selama Pandemi Covid-19. Jurnal KeperawatanJiwa.

I., C., \& P., M. (2020). COVID-19 outbreak: Migration, effects on society, global environment and prevention. Science of the Total Environment.

Karaman, M. A., Lerma, E., Vela, J. C., \& Watson, J. C. (2019). Predictors of Academic Stress Among College Students. Journal of College Counseling.https://doi.org/10.1002/jocc.12113

Khamis, H. (2008). Measures of association: How to choose? Journal of Diagnostic Medical Sonography.https://doi.org/10.1177/8756479308317006

Kohn, J. P., \& Frazer, G. H. (1986). An Academic Stress Scale: Identification and Rated Importance of Academic Stressors. Psychological Reports. https://doi.org/10.2466/pro.1986.59.2.415 
Kowalczyk, O., Roszkowski, K., Montane, X., Pawliszak, W., Tylkowski, B., \& Bajek, A. (2020). Religion and Faith Perception in a Pandemic of COVID-19. Journal of Religion and Health. https://doi.org/10.1007/s10943-020-01088-3

Kumar, S., \& Bhukar, J. P. (2013). Stress level and coping strategies of college students. Journal of Physical Education and Sport Management, 4(1), 5-11. https://doi.org/10.5897/JPESM12.001

Lazarus, R. S., \& Cohen, J. B. (1977). Environmental Stress. In Human Behavior and Environment. https://doi.org/10.1007/978-1-4684-0808-9_3

Livana, Mubin Mohammad Fatkhul \& Basthomi, Y. (2020). "Tugas Pembelajaran” Penyebab Stres Mahasiswa Selama Pandemi Covid-19. Jurnsl Ilmu Keperawatan Jiwa.

Matsumoto, D. (2009). The Cambridge Dictionary of Psychology. In Cambridge University Press. https://doi.org/10.1017/CBO9781107415324.004

Mayor, E. (2015). Gender roles and traits in stress and health. Frontiers in Psychology. https://doi.org/10.3389/fpsyg.2015.00779

Misra, R., \& Castillo, L. G. (2004). Academic stress among college students: Comparison of American and international students. International Journal of Stress Management. https://doi.org/10.1037/1072-5245.11.2.132

Muñoz-garcía, A., \& Aviles-herrera, M. J. (2014). Effects of academic dishonesty on dimensions of spiritual well-being and satisfaction: a comparative study of secondary school and university students. Assessment \& Evaluation in Higher Education, 39(3), 349-363. https://doi.org/10.1080/02602938.2013.832729

Musa, A. S., Pevalin, D. J., \& Al Khalaileh, M. A. A. (2018). Spiritual Well-Being, Depression, and Stress Among Hemodialysis Patients in Jordan. Journal of Holistic Nursing. https://doi.org/10.1177/0898010117736686

Owens, M., Stevenson, J., Hadwin, J. A., \& Norgate, R. (2012). Anxiety and depression in aca demic performance: An exploration of the mediating factors of worry and working memory. School Psychology International. https://doi.org/10.1177/0143034311427433

Pascoe, M. C., Hetrick, S. E., \& Parker, A. G. (2019). The impact of stress on students in secondary school and higher education. International Journal of Adolescence and Youth. https://doi.org/10.108o/02673843.2019.1596823

Peterson, C., \& Seligman, M. E. P. (2004). Character Strengths and Virtues: A Handbook and Classification. In Oxford University Press (p. 816). https://doi.org/10.1176/appi.ajp.162.4.820-a

Reddy, K. J., Menon, K. R., \& Thattil, A. (2018). Academic stress and its sources among university students. Biomedical and Pharmacology Journal. https://doi.org/10.13005/bpj/1404

Robotham, D. (2008). Stress among higher education students: Towards a research agenda. Higher Education. https://doi.org/10.1007/s10734-008-9137-1

S. Menaga. (2014). A Study On Academic Stress Of Higher Secondary School Students. Scholarly Research Journals.

Sarita, \& Sonia. (2015). Academic Stress among Students: Role and Responsibilities of Parents. International Journal of Aplied Researc .

Shereen, M. A., Khan, S., Kazmi, A., Bashir, N., \& Siddique, R. (2020). COVID-19 infection: Origin, transmission, and characteristics of human coronaviruses. Journal of Advanced Research. https://doi.org/10.1016/j.jare.2020.03.005

Son, C., Hegde, S., Smith, A., Wang, X., \& Sasangohar, F. (2020). Effects of COVID-19 on college students' mental health in the United States: Interview survey study. Journal of Medical Internet Research. https://doi.org/10.2196/21279

Sundayana, H. R. (2010). Statistika Penelitian Pendidikan. Bandung: Alfabeta.

Susilo, A., Rumende, C. M., Pitoyo, C. W., Santoso, W. D., Yulianti, M., Herikurniawan, H., ... 
Yunihastuti, E. (2020). Coronavirus Disease 2019: Tinjauan Literatur Terkini. Jurnal Penyakit Dalam Indonesia. https://doi.org/10.7454/jpdi.v7i1.415

VandenBos, G. R. (2015). APA dictionary of psychology, second edition. In Choice Reviews Online. https://doi.org/10.586o/choice.191867

Wang, C., Pan, R., Wan, X., Tan, Y., Xu, L., Ho, C. S., \& Ho, R. C. (2020). Immediate psychological responses and associated factors during the initial stage of the 2019 coronavirus disease (COVID-19) epidemic among the general population in China. International Journal of Environmental Research and Public Health. https://doi.org/10.3390/ijerph17051729

Wang, C., Pan, R., Wan, X., Tan, Y., Xu, L., McIntyre, R. S., ... Ho, C. (2020). A longitudinal study on the mental health of general population during the COVID-19 epidemic in China. Brain, Behavior, and Immunity. https://doi.org/10.1016/j.bbi.2020.04.028

Wilks, S. E. (2008). Resilience amid Academic Stress: The Moderating Impact of Social Support among Social Work Students. Advances in Social Work. https://doi.org/10.18060/51

Yikealo, D., Yemane, B., \& Karvinen, I. (2018). The Level of Academic and Environmental Stress among College Students: A Case in the College of Education. Open Journal of Social Sciences. https://doi.org/10.4236/jss.2018.611004 